\title{
Diet of Long-eared Owl and Common Kestrel in an urban landscape (Ukraine)
}

\author{
Ivan ZAHORODNYI ${ }^{1 *}$, Oleksii DubOVyK ${ }^{1,2}$, Ivan KoMARNYTSKYI $^{1} \&$ \\ Ihor DYKYY ${ }^{1}$
}

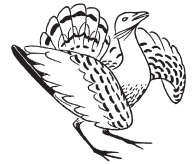

Zahorodnyi, I., Dubovyk, O., Komarnytskyi, I. \& Dykyy, I. 2021. Diet of Long-eared Owl and Common Kestrel in an urban landscape (Ukraine). - Ornis Hungarica 29(1): 108-119. DOI: 10.2478/orhu-2021-0008

\begin{abstract}
In the present study we performed a comparative dietary analysis of two predatory birds, the Longeared Owl (Asio otus) and the Common Kestrel (Falco tinnunculus) in the district of Lviv city. We found that the Long-eared Owl and the Common Kestrel are typical small mammal specialists within the urban ecosystem. Considering the abundance and biomass of prey, small mammals comprise $98.4 \%$ of the Long-eared Owl's diet. The species composition of mammals coincides almost $50 \%$ in the food intake comparison of the two birds. It has been established that the main prey of both species is the Common Vole (Microtus arvalis). The diet of the Common Kestrel is more varied, compared to the Long-eared Owl, due to the consumption of different species of insects (families Gryllotalpidae, Tettigoniidae, Carabidae and Scarabaeidae), reptiles and birds. This result suggested that dietary plasticity of the Common Kestrel facilitate successful adaptation to the urban landscape. The Long-eared Owl is more narrowly specialized in feeding on murine rodents, which reduces the trophic competition between the two predatory birds and allows the coexistence of two predators in the urban ecosystem.
\end{abstract}

Keywords: diet analysis, urban ecosystem, small mammals, Common Kestrel, Long-eared Owl

Összefoglalás Jelen tanulmányban Lviv város környezetében jellemző két ragadozó madár, az erdei fülesbagoly (Asio otus) és a vörös vércse (Falco tinnunculus) táplálkozásának összehasonlító elemzését végeztük el. Megállapítottuk, hogy Lviv város ökoszisztémájában a vörös vércse és az erdei fülesbagoly tipikus kisemlős specialista fajok. Mind az abundancia, mind a biomassza tekintetében az erdei fülesbagoly étrendjének 98,4\%-át kisemlősök tették ki. A kisemlős összetétel csaknem 50\%-ban megegyezett a két madárfaj táplálék fogyasztásának összehasonlitásában. Megállapítást nyert, hogy mindkét faj fő zsákmánya a mezei pocok (Microtus arvalis). Az erdei fülesbagollyal ellentétben a vörös vércse étrendje a különféle rovarfajok (Gryllotalpidae, Tettigoniidae, Carabidae és Scarabaeidae családok), hüllők és madarak fogyasztása miatt változatosabb. Ez a vörös vércse táplálkozási plaszticitását jelzi, amely az urbanizált tájban megkönnyíti a sikeres adaptációt. Az erdei fülesbagoly inkább az egérfélék fogyasztására specializálódott, ami csökkenti a két ragadozó madár közötti trofikus versengést, és a városi ökoszisztémában lehetővé teszi együttélésüket.

Kulcsszavak: táplálék vizsgálat, városi ökoszisztéma, kisemlősök, vörös vércse, erdei fülesbagoly

\footnotetext{
${ }^{1}$ Ivan Franko National University of Lviv, 4 Hrushevskogo Str., Lviv 79005, Ukraine

${ }^{2}$ Old Dominion University, 5115 Hampton Blvd., Norfolk 23539, Virginia, USA

*corresponding author, e-mail: Ivan.Zahorodnyy@Inu.edu.ua
} 


\section{Introduction}

The contemporary state of the world's fauna can be described by unprecedented scales of its changes, which are mainly caused by an anthropogenic factor (Zagorodniuk 2006). Within the last decades, we were able to observe intensified development of disturbed human environments. This significantly changed natural habitats (Dziemian et al. 2012), but it could also create new ecological niches for many species (Luniak 2004, Żmihorski \& Rejt 2007). Birds are exposed to significant ecological disturbance. It mainly concerns the natural populations of predatory birds, as one of the most vulnerable taxa that are forced to change their behavior and spatial distribution, which is mainly reflected in their foraging a primary physiological demand of the living organism.

The topic of changes in fauna is being actively discussed and is developing in academia. Moreover, this topic is commonly ignored in Ukraine, so that the lack of information exists in this field (Zagorodniuk 2006).

The Long-eared Owl and the Common Kestrel, as abundant raptors were chosen as model species to reveal the issues of their foraging behavior (Bokotey 2008). Birds of prey are wellknown for their dependence on the availability of prey, which may be affected by different factors: weather conditions, structure and height of the vegetation cover and agricultural activity (Tulis 2015). The hunting territories of both species are similar to some extent. Studying the diet of both species (in the future) could help to reveal the consequences of the anthropogenic pressure on both nocturnal and diurnal predators. The Long-eared Owl is one of the species of predatory birds that can be found not only in rural areas but also in big cities (Sharikov 2005). It is typically observed in forests, shrubs, parks and gardens (Fesenko \& Bokotey 2002). The diet of this owl is well studied both troughout Europe and in Ukraine (Marti 1976, Mikkola 1983, Bertolino et al. 2001, Kondratenko et al. 2001, Polishchuk, 2008, Zaitseva \& Hnatyna 2009), which can be explained by its widespread occurrence and high abundance (Gavrilyuk et al. 2009, Drebet 2013), but no special trophic studies of this species were conducted in Lviv.

As a common rule, the diet of the Long-eared Owl tipically consists of 1-3 small mammal species that belong to the Arvicolidae family (Cherkashchenko 1960, Marti 1976, Drebet 2009, Stasiak et al. 2012). Despite this fact, the latest updates show that this species performs trophic adaptations, which lead to the increase of the consumed prey diversity in Europe (Bertolino et al. 2001). For sedentary species, adjustment to new trophic conditions can be crucial during winter when food availability decreases (Żmihorski \& Rejt 2007). Therefore, studying the changes in the diet with regards to seasonal and temporal patterns remains important, especially given the rapid changes in habitats (Drebet 2011).

The Common Kestrel is the most abundant bird of prey in urban habitats of the Western Palearctic (Cramp \& Simmons 1980). Most of the nesting pairs of urban colonies are located on high buildings adjacent to parks or other greenery, especially on the periphery of a city with developing construction. However, open habitats with a mosaic of small forests are the typical habitat for this species in the wild (Zubarovsky 1977). Some adaptive traits in the biology and ecology of this species, such as the diet, have changed after the invasion to urban ecosystems (Rejt 2007). The most obvious reactions of raptors to food shortages 
are expanding the diet to alternative prey (Korpimäki 1986, Reif et al. 2001, Riegert et al. 2007). Urban Kestrels have an excellent opportunity to feed on birds, as their availability does not usually change markedly between years (Riegert et al. 2007).

The aim of this work is to reveal the diet, size of the prey, and foraging strategy of the Long-eared Owl and the Common Kestrel in Lviv and to compare them.

\section{Materials and Methods}

The research was conducted in the territory of Lviv, one of the largest cities in Ukraine. It is located in the forest-steppe region of the western part of the Volyn-Podilska Upland, in the valley of the Poltva river (Vistula/Baltic Sea basin) and on the slopes of the surrounding hills (Gerenchuk 1972). The built-up area of the city with parks and forest parks surrounded by buildings (ecological boundaries of the city) is $66.7 \mathrm{~km}^{2}$ (Bokotey 2008). Materials for this study were collected in the territory of Halych, Lychakiv, Sykhiv districts and on the outskirts of the city (near the village of Solonka): central, eastern, south-eastern and southern parts of the city, respectively.

We carried out the field collection of pellets and prey residues during the nesting and nonnesting periods in resting places, under perches, and also in the birds' nests and under them. This method is widely used to study the spectrum of bird feeding. Pidoplichka $(1932,1937)$ was the first scientist in Ukraine who studied pellets to describe the diet of birds of prey. This method has become popular in the work of other researchers (Cherkashchenko 1960, Zaitseva \& Hnatyna 2009, Stasiak et al. 2012 and many others) and replaced the analysis of stomach contents of birds, which requires the removal of animals from native habitat. Nowadays, the analysis of pellets of birds of prey has become relevant again due to the necessity of using cheap and non-invasive methods of material collecting without disturbing populations (Atamas 2002, Kuznetsov \& Kondratenko 2006, Zaytseva \& Drebet 2007). In addition, pellet analysis allows to study the trophic relationships between predators and prey in different ecosystems (Atamas 2004).

The bigger part of pellets of the Long-eared Owl was collected in daytime resting places in the winter-spring period and also in early October of 2015. October collection contained pellets from both autumn and summer period, which allows us to assess the feeding of this species throughout the year. The Long-eared Owl uses trees for the day rest (the norway spruce Picea abies and the northern white-cedar Thuja occidentalis), as the crown protects birds from the adverse effects of weather conditions (e.g. wind, precipitation). The trees were located in the area of a horse racetrack. Overall, 665 Long-eared Owl pellets were collected and analyzed, and 1618 food items were identified.

The pellets of the Common Kestrel were collected from March to August in 2014-2015, which represents the entire period the birds stayed in the nesting area (kestrels stay in Lviv in winter in rare cases). Overall, 527 pellets and prey remains of this species were collected and analyzed. Altogether, 599 food items were identified.

Identification of small mammal species was performed according to the characteristics of the structure of the skull, jaws, teeth and dentition (for mammals); feathers, skeletal 
remains, as well as the shape and size of the beak (for birds); head shields and scales (for reptiles); the presence of forewings, wings and chitinous covers (for insects) (Vinogradov \& Argyropulo 1941). The biomass value was obtained from literature sources (Pucek 1984, Romanowski 1988, Dietz et al. 2009, Kitowski 2013).

We calculated the percentage ratio in the total dietary biomass for each food item and the frequency of their occurrence. The average body weight used to estimate the biomass of prey is presented in Table 1, while for invertebrates, the average weight is $0.5 \mathrm{~g}$ for each specimen. To compare the mean biomass of prey we used it's abundance weighted by predicted biomass. Since the abundance of a certain prey can be expressed as a proportion of this prey in the diet of a raptor, it is possible to apply a binomial test to compare two proportions (Crawley 2007), which was done both for abundance and biomass data.

All calculations were made using R programming language (R Core Team 2020).

\section{Results}

According to the pellet analysis, it was established that the basis of the diet of both studied species within the city of Lviv are small mammals. In contrast, insects are rare in the diet of the Long-eared Owl, and reptiles have not been observed (Table 1). However, these species play a significant role in the feeding of the Common Kestrel in certain periods (see below). Small mammals comprise $98.4 \%$ of the diet of the Long-eared Owls in number and biomass. 13 species of small mammals were identified in total. The most abundant species were Microtus arvalis (75.6\% in number and $72.1 \%$ in biomass), Microtus agrestis (5\% and $5.8 \%$ ), Apodemus agrarius (5.1\% and 4.4\%), Sylvaemus sylvaticus (4.3\% and $4.3 \%)$ and Nyctalus noctula (3.6\% and 4.7\%). Birds (5 species) amount to $1.4 \%$ in number and $1.6 \%$ in biomass. Insects, particularly Melolontha melolontha, were found in only four pellets (a total of 4 individuals). They are less than $1 \%$ in both quantity and biomass. It has been found that the average weight of the Long-eared Owl's prey is $30.2 \mathrm{~g}$ (range $0.5-238 \mathrm{~g}$ ).

According to our data, mammals comprise $71.8 \%$ by abundance and $79.9 \%$ by biomass in the diet of the Common Kestrel. 6 species of mammals were identified in the analysis of pellets. The main prey among them was Microtus arvalis (68.9\% by abundance and $75 \%$ by biomass), followed by other rodents: Microtus agrestis (1.3\% and $1.6 \%$ respectively), Apodemus agrarius (1\% and $0.9 \%$ respectively). Birds ( 7 species) amounted to $4.4 \%$ of the diet by quantity and $14.7 \%$ by biomass. Reptiles also play a significant role in the nutrition of the Common Kestrel in the study areas (6.9\% in number and 5\% in biomass), which are represented by only one species - Lacerta agilis. Insects belonging to the orders Orthoptera and Coleoptera have also been found in the diet of the Common Kestrel. The members of the families Gryllotalpidae and Tettigoniidae among the Orthoptera and representatives of the families Carabidae and Scarabaeidae among the beetles were found in the diet of the Common Kestrel. Insects comprised $16.8 \%$ of the diet in terms of quantity, but only $0.5 \%$ in biomass. The average weight of the prey was $52 \mathrm{~g}$ (range $0.5-238 \mathrm{~g}$ ).

It is notable that some individuals of the Common Kestrel can consume some anthropogenic inedible materials such as styrofoam and cotton, which were found in 30 samples; in 2 cases 
Table 1. Diet composition of Asio otus and Falco tinnunculus in the area of Lviv. MNI - minimum number of individuals

1. táblázat Az erdei fülesbagoly és a vörös vércse táplálék-összetétele Lviv város területén. MNI minimum ismert egyedszám

\begin{tabular}{|c|c|c|c|c|c|c|c|c|c|}
\hline \multicolumn{4}{|c|}{$\begin{array}{l}\text { number and frequency of } \\
\text { occurrence }\end{array}$} & \multirow{3}{*}{$\begin{array}{l}\text { Object of nutrition, } \\
\text { Species }\end{array}$} & \multirow{3}{*}{$\begin{array}{c}\text { Average } \\
\text { body } \\
\text { weight, g }\end{array}$} & \multicolumn{4}{|c|}{ biomass of the food object } \\
\hline \multicolumn{2}{|c|}{ Asio otus } & \multicolumn{2}{|c|}{$\begin{array}{c}\text { Falco } \\
\text { tinnunculus }\end{array}$} & & & \multicolumn{2}{|c|}{ Asio otus } & \multicolumn{2}{|c|}{$\begin{array}{c}\text { Falco } \\
\text { tinnunculus }\end{array}$} \\
\hline MNI & $\begin{array}{c}\text { MNI } \\
\%\end{array}$ & MNI & $\begin{array}{c}\text { MNI } \\
\%\end{array}$ & & & MNI g & $\begin{array}{c}\text { MNI g } \\
\%\end{array}$ & MNI g & $\begin{array}{c}\text { MNI g } \\
\%\end{array}$ \\
\hline 9 & 0.6 & 0 & 0.0 & Micromys minutus & 8 & 72 & 0.2 & 0 & 0.0 \\
\hline 83 & 5.1 & 7 & 1.0 & Apodemus agrarius & 17 & 1411 & 4.4 & 119 & 0.9 \\
\hline 18 & 1.1 & 0 & 0.0 & Sylvaemus tauricus & 31 & 558 & 1.7 & 0 & 0.0 \\
\hline 69 & 4.3 & 1 & 0.1 & Sylvaemus sylvaticus & 20 & 1380 & 4.3 & 20 & 0.2 \\
\hline 28 & 1.7 & 0 & 0.0 & Sylvaemus uralensis & 19 & 532 & 1.6 & 0 & 0.0 \\
\hline 11 & 0.7 & 0 & 0.0 & Mus musculus & 15.5 & 170.5 & 0.5 & 0 & 0.0 \\
\hline 4 & 0.2 & 1 & 0.1 & Rattus norvegicus & 238 & 952 & 2.9 & 238 & 1.9 \\
\hline 222 & 13.7 & 9 & 1.3 & Muridae & & 5075.5 & 15.7 & 377 & 3.0 \\
\hline 1227 & 75.6 & 496 & 68.9 & Microtus arvalis & 19 & 23313 & 72.1 & 9424 & 75.0 \\
\hline 81 & 5.0 & 9 & 1.3 & Microtus agrestis & 23 & 1863 & 5.8 & 207 & 1.6 \\
\hline 1308 & 80.6 & 505 & 70.1 & Arvicolidae & & 25176 & \begin{tabular}{|l|l}
77.9 \\
\end{tabular} & 9631 & 76.7 \\
\hline 4 & 0.2 & 3 & 0.4 & Sorex araneus & 8 & 32 & 0.1 & 24 & 0.2 \\
\hline 1 & 0.1 & 0 & 0.0 & Sorex minutus & 3.5 & 3.5 & 0.01 & 0 & 0.0 \\
\hline 2 & 0.1 & 0 & 0.0 & Crocidura leucodon & 8 & 16 & 0.05 & 0 & 0.0 \\
\hline 7 & 0.4 & 3 & 0.4 & Soricidae & & 51.5 & 0.2 & 24 & 0.2 \\
\hline 59 & 3.6 & 0 & 0.0 & Nyctalus noctula & 25.5 & 1504.5 & 4.7 & 0 & 0.0 \\
\hline 1596 & 98.4 & 517 & 71.8 & MAMMALIA & & 31807.5 & 98.4 & 10032 & 79.9 \\
\hline 5 & 0.3 & 14 & 1.9 & Parus major & 17.5 & 87.5 & 0.3 & 245 & 2.0 \\
\hline 0 & 0.0 & 4 & 0.6 & Cyanistes caeruleus & 10.5 & 0 & 0.0 & 42 & 0.3 \\
\hline 0 & 0.0 & 2 & 0.3 & Turdus sp. & 94 & 0 & 0.0 & 188 & 1.5 \\
\hline 12 & 0.7 & 4 & 0.6 & Passer domesticus/montanus & 24.5 & 294 & 0.9 & 98 & 0.8 \\
\hline 1 & 0.1 & 1 & 0.1 & Emberiza citrinella/schoeniclus & 23 & 23 & 0.1 & 23 & 0.2 \\
\hline 3 & 0.2 & 0 & 0.0 & Pyrrhula pyrrhula & 27.5 & 82.5 & 0.3 & 0 & 0.0 \\
\hline 1 & 0.1 & 1 & 0.1 & Carduelis carduelis & 16 & 16.0 & 0.05 & 16 & 0.1 \\
\hline 0 & 0.0 & 6 & 0.8 & Columba livia juv & 205 & 0.0 & 0.0 & 1230 & 9.8 \\
\hline 22 & 1.4 & 32 & 4.4 & AVES & & 503.0 & 1.6 & 1842 & 14.7 \\
\hline 0 & 0.0 & 50 & 6.9 & Lacerta agilis & 12.5 & 0 & 0.0 & 625 & 5.0 \\
\hline 0 & 0.0 & 50 & 6.9 & REPTILIA & & 0 & 0.0 & 625 & 5.0 \\
\hline 4 & 0.2 & 121 & 16.8 & INSECTA & 0.5 & 2.0 & 0.01 & 60,5 & 0.5 \\
\hline 1622 & 100 & 720 & 100 & \multicolumn{2}{|l|}{ In general } & 32312.5 & 100 & 12559.5 & 100 \\
\hline & & & & \multicolumn{2}{|l|}{ Number of pellets } & \multicolumn{2}{|c|}{665} & \multicolumn{2}{|c|}{527} \\
\hline
\end{tabular}


the pellet was entirely styrofoam. But those cases are related only to one pair of raptors which made its nest in a cavity isolated by a sheet of styrofoam.

The overlap of trophic niches in these two species was considerable. Jaccard index was 0.45 , but it represents only the similarity of presence/absence data. We also used BrayCurtis index, which showed that Jaccard index was relevant in our case: this index shows 0.45 overlap by abundance of prey and 0.46 overlap by its biomass.

The Long-eared Owl prefers to hunt bigger prey than the Common Kestrel (Table 2). This slightly contrasts with the average body mass of prey objects: there is a bigger biomass in

Table 2. Comparison of food item abundance and biomass in the diet of the Long-eared Owl and the Common Kestrel in Lviv (Ukraine)

2. táblázat $\mathrm{Az}$ erdei fülesbagoly és a vörös vércse táplálék-összetételének összehasonlítása a táplálékfajok abundanciája és biomasszája alapján Lviv városban (Ukrajna)

\begin{tabular}{|c|c|c|c|c|}
\hline \multirow{3}{*}{ Prey } & \multicolumn{4}{|c|}{ Binomial proportion test } \\
\hline & \multicolumn{2}{|c|}{ Abundance } & \multicolumn{2}{|c|}{ Biomass } \\
\hline & $x^{2}$ & $\mathbf{p}$ & $x^{2}$ & $\mathbf{p}$ \\
\hline Micromys minutus & 2.765 & 0.096 & 27.228 & $<0.001$ \\
\hline Apodemus agrarius & 22.768 & $<0.001$ & 132.681 & $<0.001$ \\
\hline Sylvaemus tauricus & 6.820 & 0.009 & 222.798 & $<0.001$ \\
\hline Sylvaemus sylvaticus & 28.352 & $<0.001$ & 516.038 & $<0.001$ \\
\hline Sylvaemus uralensis & 11.412 & 0.001 & 212.224 & $<0.001$ \\
\hline Mus musculus & 3.654 & 0.056 & 66.508 & $<0.001$ \\
\hline Rattus norvegicus & 0.003 & 0.954 & 42.048 & $<0.001$ \\
\hline Microtus arvalis & 16.733 & $<0.001$ & 9.202 & 0.002 \\
\hline Microtus agrestis & 18.555 & $<0.001$ & 360.828 & $<0.001$ \\
\hline Sorex araneus & 0.067 & 0.796 & 5.071 & 0.024 \\
\hline Sorex minutus & 0.000 & 1.000 & 0.343 & 0.558 \\
\hline Crocidura leucodon & 0.036 & 0.850 & 5.029 & 0.025 \\
\hline Nyctalus noctula & 25.952 & $<0.001$ & 616.553 & $<0.001$ \\
\hline Parus major & 14.188 & $<0.001$ & 335.558 & $<0.001$ \\
\hline Cyanistes caeruleus & 5.922 & 0.015 & 102.477 & $<0.001$ \\
\hline Turdus sp. & 1.791 & 0.181 & 472.400 & $<0.001$ \\
\hline Passer domesticus/montanus & 0.070 & 0.791 & 2.087 & 0.149 \\
\hline Emberiza citrinella/schoeniclus & 0.000 & 1.000 & 9.525 & 0.002 \\
\hline Pyrrhula pyrrhula & 0.295 & 0.587 & 31.406 & $<0.001$ \\
\hline Carduelis carduelis & 0.000 & 1.000 & 6.320 & 0.012 \\
\hline Columba livia juv & 10.254 & 0.001 & 3186.085 & $<0.001$ \\
\hline Lacerta agilis & 109.479 & $<0.001$ & 1594.595 & $<0.001$ \\
\hline Insects & 261.619 & $<0.001$ & 140.633 & $<0.001$ \\
\hline Styrofoam & 21.273 & $<0.001$ & & \\
\hline Cotton & 5.922 & 0.015 & & \\
\hline
\end{tabular}


prey objects of the Common Kestrel than of the Long-eared Owl. But after the exclusion of non-typical rare objects (Rattus norvegicus, Turdus sp., Columba livia juv) we can easily see that a typical prey of the Long-eared Owl is bigger (18.2 g) than of the Common Kestrel (14.7 g). Taking into account the abundance of prey, the typical prey unit in the Long-eared Owl was $33.25 \pm 22.44 \mathrm{~g}$ vs. $18.37 \pm 21.75 \mathrm{~g}$ in the Common Kestrel. It is found that abundances of 16 prey types (Table 2) out of 25 are significantly different in the diets of the two species. But the comparison of the proportion of the prey in the diet by abundance shows that 14 prey types are significantly different and almost all proportions by biomass (except Sorex minutus and Passer sp.) are different in the diets of the Long-eared Owl and the Common Kestrel (Table 2). Both Sorex minutus and Passer sp. were presented in extremely low numbers (Table 1), so this result more probably indicates that both the Common Kestrel and the Long-eared Owl consume these preys extremely rare. More generally, the above results imply that the diets of the two species of raptors do not overlap by biomass proportions.

\section{Discussion}

The results of analysis of the Long-eared Owl's foraging preferences in Lviv fit a considerable body of literature, which shows that this owl is a specialist in catching small rodents such as Microtus sp., but those preferences could change throughout the year (Polishchuk 2008). A huge part of the Long-eared Owl's diet consists of Microtus arvalis, which is a typical species of rural landscapes, agricultural lands and cities. Despite the fact that the abundance of this species is lower in urban areas, it is still the most abundant in the owl's diet (Harmata 1969, Wendland 1984, Romanowski \& Zmihorski 2008, Riegert et al. 2009, Drebet 2011). The diversity of murines in the diet of the Long-eared Owl can be explained by the fact that our study sites were located near a horse stable, which provides an extremely suitable habitat for those rodents. Also, the landscape is heterogeneous due to a high diversity of trees and shrubs and the presence of open lands patches, which provide a habitat for different species of rodents and a good location for hunting (Marzluff \& Rodewald 2008).

It is a well-established fact that the number of bats in the Long-eared Owl's diet is normally low (Zaytseva \& Drebet 2007, Drebet 2013). Because the bats are the rare prey of the owls, the assessment of their relations could be complicated. We have observed cases of bats' presence in the diet of the Long-eared Owls, but those cases were rare which points out the fact that such events are occasional. The only one bat species - Nyctalus noctulacomprised only $3.6 \%$ of the Long-eared Owl's diet. We assume that those pellets that were collected in March contained the Nyctalus bats that were predated during the fall because this species has a considerable hibernation period. We think that a big number of preyed bats are related to several specialized individuals who learned how to hunt near the exit from the mother colony of bats. Some cases of in-air hunting are known, but they are rare (Polishchuk 2008). It is noticeable that the wintering sites were located in the same places from year to year, which are close to the bats' colonies. Although the bats are not thought to be considerable in the owl's diet in Lviv, sometimes they can be locally abundant in pellets 
of the Long-eared Owls near mother colonies and/or in periods of fall flocking. Considering those facts, we confirm that bats are random and not regular prey of the Long-eared Owl.

The insects are also rare in the owl's diet. In particular, insects are completely absent in the diet of this species from the territory of České Budějovice (Riegert et al. 2009). In our research area, insects can be found during springs and summers. Only Melolontha melolontha can be observed in the Long-eared Owl's diet rarely $(0.2 \%)$. Also, birds are rare but regular prey $(1.4 \%)$ of the owls, so those prey are sporadic.

The diet of raptors may change when they inhabit urban areas. For example, Kestrels in large cities often enrich their diet with birds (Witkowski 1962, Beichle 1980, Romanowski 1996). However, we did not observe such a switching in Lviv. The proportion of birds was consistently low, as in Kestrels in České Budějovice (Riegert et al. 2009). The diet of the Common Kestrel consists mostly of small rodents similarly to the Long-eared Owl. Birds, reptiles, and insects are minor prey for this falcon. We revealed that according to our data collected in 2014, 72.8\% of the prey was Microtus arvalis and $65.7 \%$ in 2015. There are much lower abundances of Microtus agrestis (2.8\%), Sylvaemus sylvaticus $(0.3 \%)$, Apodemus agrarius (0.3\%) in the Common Kestrel's diet.

The percentage of insects was twice higher in 2015 compared to 2014 (10.5\% vs. 21.9\%) in the Common Kestrel's diet. The numbers of birds were the same compared to 2014, but we have not observed Microtus agrestis and Sylvaemus sylvaticus and have observed Sorex araneus $(\mathrm{n}=3)$ instead. Artificial materials such as cotton and styrofoam were not observed, which can be explained by nest site features of the defined pair mentioned above.

The analysis of the Common Kestrel's pellets collected in 2014-2015 allows us to assume that the diet of this falcon species is broad: at least 15 types of prey were observed (Table 1). We divided all those types into 3 main groups: major, additional, and occasional. Microtus arvalis is identified as a major prey (68.9\%); insects, birds, and reptiles are thought to be additional prey $(16.5 \%, 4.4 \%$, and $6.9 \%$, respectively), which are used in cases of obstacles to feed on major preys or in cases of low abundances of Microtus arvalis (Riegert \& Fuchs 2004). Temporal availability changes in some types of resources could be one more reason to use additional resources: for example, there are distinct spikes in Melolontha melolontha abundances in May. Other resources are those which comprise less than $0.5 \%$ and are occasional.

The Common Kestrel's diet is more diverse compared to the Long-eared Owl, because it includes several species of insects (from families of Gryllotalpidae, Tettigoniidae, Carabidae, Scarabaeidae) and reptiles. It shows the reduction of the hunting specialization in the Common Kestrel. But the role of insects in the Common Kestrel's diet is overestimated, in our opinion: many researchers calculate abundance only, which leads to overestimations because of a big number of exoskeletons fragments (elytron and other chitin-rich parts) in pellets. Despite this fact, the biomass percentage of insects is much lower: $16.8 \%$ by abundance and $0.5 \%$ by biomass according to our data.

Riegert et al. (2009) examined the possible relationship between the distance from a nest to the city centre and the proportion of voles in the diet of the two species. The Kestrel diet was not markedly influenced by distance, but for Long-eared Owls, an increasing distance was associated with an increasing dietary proportion of voles. The difference between the 
two species is confirmed by results on hunting activities revealed by telemetry and wingtagging. Kestrels almost exclusively hunt in rural areas (Riegert et al. 2007), Long-eared Owls often hunt in edge habitats within the city area (Lövy 2007). Such habitats host a high diversity of small mammals, especially Muridae (Briner et al. 2005, Suchomel \& Heroldová 2006).

Thus, the diets of both raptors consist mostly of small mammals, birds and insects in the urban landscapes, but the diet of the Common Kestrel also includes reptiles (7\%), which is a considerable addition. 98.4\% of the Long-eared Owl's diet is small mammals. Only 6 out of 13 species registered are common in the diets of both species.

\section{Selectivity}

It is known that the percentage of rodents in the diet of the predator, in part, depends on their numbers. In polyphagous predators, there is a relationship between the large number of rodents and their share in the diet of predators. However, specialized predators consume the high proportion of desired prey even with low prey numbers (Andersson \& Erlinge 1977, Romanowski 1988).

The Long-eared Owl, like the Common Kestrel, showed similar preferences for small rodents. The main food for both species is $M$. arvalis. Lack of variety of preferences for other species of small rodents indicates the existence of a common mechanism to choose prey for both species. Predominance of $M$. arvalis in the diet is due to the additive effect of the size of the predator and the number of prey. The size of M. arvalis is in the optimal range of prey size for both the Long-eared Owl and the Common Kestrel. Also, this scheme of prey selection is probably associated with several characteristics, such as daily and seasonal activity, mobility, spatial distribution, and most importantly, the colonial lifestyle of $M$. arvalis. The organization of their populations is based on a system of colonies (Romanowski 1988). The size of the colonies can range from a few to a dozen or more individuals. Probably, this feature of distribution of $M$. arvalis has led to the fact that many birds of prey specialize in hunting this species. It should be noted that this species is also one of the best adapted small rodents to live in highly transformed agricultural lands with frequent plowing. This feature allows $M$. arvalis to dominate by the number in small rodent communities in most of its range.

\section{Conclusions}

It has been found that within the urban ecosystem of Lviv, the Long-eared Owl and the Common Kestrel are typical small mammal specialist.

We found that the main food object is $M$. arvalis in both species. The lack of preferences in diet to other species of small rodents indicates the existence of a common mechanism for prey choice for both species. We assume that the size of M. arvalis is in the optimal range of prey size. We consider that the principle of prey choice in the studied bird species is associated with several characteristics of $M$. arvalis, such as daily and seasonal activity, mobility, spatial 
distribution, and most importantly, its colonial way of life and that this rodent species was the most abundant and thus, the most available prey. These biological features of M. arvalis encourage most birds of prey to specialize in hunting this species of rodent.

Unlike the Long-eared Owl, the diet of the Common Kestrel is more variable due to the consumption of different species of insects (families Gryllotalpidae, Tettigoniidae, Carabidae and Scarabaeidae) $-4 / 1$, reptiles $-1 / 0$ and birds $-7 / 5$. This result suggested that dietary plasticity of the Common Kestrel facilitate successful adaptation to the urban landscape.

It has been found that small mammals comprise $98.4 \%$ in number and biomass of the diet of Long-eared Owls. Thus, the Long-eared Owl within Lviv territory is a typically theriophage with a slight manifestation of entomophagy, in contrast to the polyphagous Common Kestrel, which acts as a typical theriophage with elements of herpeto-, entomoand ornithophagy. In summary, the Long-eared Owl is more strictly specialized in feeding on murine rodents that reduces trophic competition between the two species of predators in the urban ecosystem and coexists freely in the same types of habitats.

\section{Acknowledgements}

We would like to thank Petro Hryniuk and Ihor Shydlovskyy for their valuable support, critical reading of the manuscript, making useful suggestions and bibliographic assistance.

\section{References}

Andersson, M. \& Erlinge, S. 1977. Influence of predation on rodent populations. - Oikos 29: 591-597. DOI: $10.2307 / 3543597$

Atamas, N. 2002. Використання пелеток птахів родини Laridae під час вивчення мікротеріофауни [Treatment of pellets from the birds of family Laridae for study of small mammal fauna]. - Visnyk of Lviv University 30: 3-7. (in Ukrainian)

Atamas, N. 2004. Особливості дослідження мікротеріофауни шляхом аналізу вмісту пелеток хижих птахів [Some peculiarities of using the droppings of birds of prey for study of small mammals fauna]. - Visnyk of Lviv University 38: 133-136. (in Ukrainian)

Beichle, U. 1980. Siedlungsdichte, Jagdreviere und Jangdweise des Turmfalken (Falco tinnunculus) im Stadtgebiet von Kiel [Settlement density, hunting grounds and areas of the Kestrel (Falco tinnunculus) in the urban area of Kiel]. - Corax 8: 3-12. (in German)

Bertolino, S., Ghiberti, E. \& Perrone, A. 2001. Feeding ecology of the Long-eared Owl (Asio otus) in Northern Italy: is it a dietary specialist. - Canadian Journal of Zoology 79(12): 2192-2198. DOI: 10.1139/z01-182

Bokotey, А. 2008. Гніздова орнітофауна міста Львова та основні причини ії змін (за результатами складання гніздових атласів птахів у 1994-1995 та 2005-2007рp.) [Changes in breeding avifauna of Lviv City and their causes (basing on the results of compiling the ornithological atlases in 1994-1995 and 2005-2007)]. Scientific Bulletin of the Uzhhorod University 23: 17-25. (in Ukrainian)

Briner, T., Nentwig, W. \& Airoldi, J. P. 2005. Habitat quality of wildflower strips for Common Voles (Microtus arvalis) and its relevance for agriculture. - Agriculture, Ecosystems and Environment 105: 173-179. DOI: 10.1016/j.agee.2004.04.007

Cherkashchenko, M. 1960. Значення мишовидних гризунів в живленні сови вухатої [Significance of mouselike rodents in the diet of the Eared Owl]. - Proceedings of the Natural History Museum of the Ukrainian SSR Academy of Science 8: 120-123. (in Russian)

Cramp, S. \& Simmons, K. E. L. 1980. The Birds of the Western Palearctic. - Oxford University Press, Oxford

Crawley, M. J. 2007. The R Book. - John Wiley \& Sons, Hoboken, DOI: 10.1002/9780470515075

Dietz, C., Helversen, O. \& Nill, D. 2009. Bats of Britain, Europe and Northwest Africa. - A \& C Black, London 
Drebet, M. 2009. Питание ушастой совы на территории Каменецкого Приднестровья, Подолье, Украина [Diet of the Long-eared Owl in the Dniester area of Kamenets, Podillia, Ukraine]. - Owls of the Northern Eurasia: ecology, spatial and habitat distribution, pp. 55-59. (in Russian)

Drebet, M. 2011. Живлення сови вухатої (Asio otus L.) на Північному Поділлі [Diet of Long-eared Owl Asio otus L. in the Northern Podillya]. - Proceedings of the State Natural History Museum 27: 127-132. (in Ukrainian)

Drebet, M. 2013. Зимовий аспект харчування сови вухатої (Asio otus L.) в Кам'янці Подільському та роль рукокрилих ссавців в іiі раціоні [Winter aspect of foraging of the Long-eared Owl (Asio otus L.) in Kamianets-Podilskyi and the role of chiroptera in its diet]. - The Transactions of the Azov-Black Sea Ornithological Station «Branta» 16: 98-106. (in Ukrainian)

Dziemian, S., Piłacińska, B. \& Pitucha, G. 2012. Winter diet composition of urban Long-eared Owls (Asio otus) in Rzeszów (SE Poland). - Biological Letters 49(2): 107-114.

Fesenko, G. \& Bokotey, А. 2002. Птахи фауни України: польовий визначник [Birds of Ukraine: a field guide]. - Kyiv (in Ukrainian)

Gavrilyuk, M., Kuzmenko, Yu. \& Bashta, A-T. 2009. Кадастр мест встреч ушастых сов (Asio otus) в Украине [Inventory of sites of records of the Long-eared Owls (Asio otus) in Ukraine]. - Ukrainian Birds of Prey Research Centre, pp. 1-8. (in Russian)

Gerenchuk, K. 1972. Природа Львівської області [Nature of the Lviv region]. - Ivan Franko National University of Lviv, Lviv (in Ukrainian)

Harmata, W. 1969. Analiza pokarmu sowy uszatej, Asio otus rezerwatu Lekezak k. Raciborza w woj. opolskim [Diet analysis of Long-eared Owl (Asio otus) from Łężczak reserve near Racibórz in Opole Province]. Przeglad Zoologiczny 13: 98-101. (in Polish)

Hespenheide, H. 1973. Ecological inferences from morphological data. - Annual Review of Ecology, Evolution, and Systematics 4: 213-229.

Kitowski, I. 2013. Winter diet of the Barn Owl (Tyto alba) and the Long-Eared Owl (Asio otus) in Eastern Poland. - North-Western Journal of Zoology 9(1): 16-22.

Kondratenko, A., Kuznetsov, V. \& Timoshenkov, V. 2001. Особенности питания ушастой совы (Asio otus) в Донецко-Донских и Приазовских степях [Features of feeding of the owl (Asio otus) in the Donetsk-Don and Priazov steppes]. - Newsletter of the Luhansk Sovereign Pedagogical University of the Name of Taras Shevchenko 6(38): 116-120. (in Russian)

Korpimäki, E. 1986. Diet variation, hunting habitat and reproductive output of the Kestrel Falco tinnunculus in the light of the optimal diet theory. - Ornis Fennica 63(3): 84-90.

Kuznetsov, V. \& Kondratenko, O. 2006. Мікротеріофауна заповідних територій Луганщини за результатами аналізу погадок хижих птахів [Small mammal fauna of reserved territories of the Luhansk province after results of the birds of prey pellets analysis]. - Proceedings of Theriological School 7: 75-76. (in Ukrainian)

Lövy, M. 2007. Ekologie krmení ušatek ušatých (Asio otus) v městském prostředí [Feeding ecology of Longeared Owls (Asio otus) in urban habitat]. - MSc Thesis, University of South Bohemia, Ėeské Budijovice (in Czech)

Luniak, M. 2004. Synurbization - adaptation of animal wildlife to urban development. - In: Shaw, W. W., Harris, L. K. \& Vandruff, L. (eds.) Proceedings of the $4^{\text {th }}$ International Symposium on Urban Wildlife Conservation, Tucson, pp. 50-55.

Marti, C. 1976. A review of prey selection by the Long-eared Owl. - Condor 78: 331-336.

Marzluff, J. \& Rodewald, A. 2008. Conserving biodiversity in urbanizing areas: Nontraditional views from a Bird's perspective. - Cities and the Environment (CATE) 1(2): 1-27. DOI: 10.15365/cate.1262008

Mikkola, H. 1983. Owls of Europe. - Poyser T \& Calton AD, London

Pidoplichka, I. 1932. Аналізи погадок за 1925-1929 pp. [Analysis of pellets from 1925-1929]. - Materials for the Regional Study of Small Animals and Birds That Feed on Them 1: 1-76. (in Ukrainian)

Pidoplichka, I. 1937. Підсумки дослідження погадок за 1924-1935 pp. [Summary of bird pellets research in 1924-1935]. - Zbirnyk Prats Zoologichnoho Muzeiu 19: 101-170. (in Ukrainian)

Polishchuk, I. 2008. Влияние снежного покрова на рацион ушастой совы (Asio otus L.) [Influence of the snow cover on the diet of the Eared Owl (Asio otus L.) in the Askania-Nova Biosphere Reserve]. - Recent Research of Falcons and Owls: Proceedings of the III. International Scientific Conference «Birds of Prey of Ukraine», pp. 312-318. (in Russian)

Pucek, Z. 1984. Klucz do oznaczania ssaków Polski [Key to the identification of Polish mammals]. - PWN, Warsaw (in Polish) 
Riegert, J. \& Fuchs, R. 2004. Insects in the diet of urban Kestrels from central Europe: an alternative prey or constant component of the diet? - Ornis Fennica 81: 23-32.

Riegert, J., Dufek, A., Fainová, D., Mikeš, V. \& Fuchs, R. 2007. Increased hunting effort buffers against vole scarcity in an urban Kestrel Falco tinnunculus population. - Bird Study 54(3): 353-361. DOI: 10.1080/ 00063650709461495

Riegert, J., Lövy, M. \& Fainová, D. 2009. Diet composition of Common Kestrels Falco tinnunculus and Longeared Owls Asio otus coexisting in an urban environment. - Ornis Fennica 86(4): 123-130.

Reif, V., Tornberg, R., Jungell, S. \& Korpimäki, E. 2001. Diet variation of Common Buzzards supports the alternative prey hypothesis. - Ecography 24: 267-274.

Rejt, L. 2007. Breeding biology of urban Kestrel Falco tinnunculus in Warsaw. - PhD Thesis, Museum and Institute of Zoology, Polish Academy of Sciences. DOI: 10.1007/s10336-005-0089-2

Romanowski, J. 1988. Trophic ecology of Asio otus (L.) and Athene noctua (Scop.) in the suburbs of Warsaw. Polish Ecological Studies 14(1-2): 223-234.

Romanowski, J. 1996. On the diet of urban Kestrels (Falco tinnunculus) in Warsaw. - Buteo 8: 123-130.

Romanowski, J. \& Zmihorski, M. 2008. Effect of season, weather and habitat on diet variation of a feeding-specialist: A case study of the Long-eared Owl, Asio otus in Central Poland. - Folia Zoologica 57(4): 411-419.

Sharikov, A. 2005. Фауна сов города Москвы [Owls of Moscow]. - Owls of the Northern Eurasia, pp. $455-461$. (in Russian)

Stasiak, K., Kitowski, I., Wisniowski, R., Pitucha, G., Krawczyk, R., Cios, S., Grzywaczewski, G. \& Bashta, A-T. 2012. Food composition of Long-eared Owl (Asio otus) from Poland and Ukraine during non-breeding season. - Berkut 21(1-2): 93-97.

Suchomel, J. \& Heroldová, M. 2006. Diversity of small mammal communities in two semiartificial wooded habitats. - Hystrix - The Italian Journal of Mammalogy 17: 179-182.

Tulis, F., Baláž, M., Obuch, J. \& Šotnár, K. 2015. Responses of the Long-eared Owl Asio otus diet and the numbers of wintering individuals to changing abundance of the Common Vole Microtus arvalis. - Biologia 70(5): 667-673. DOI:10.1515/biolog-2015-0074

Vinogradov, B. \& Argyropulo, А. 1941. Определитель грызунов. Фауна СССР. Млекопитающие [The kеуs on Rodents. Fauna of the USSR: the mammals]. - Academy of Sciences Publishing House USSR, MoscowLeningrad (in Russian)

Wendland, V. 1984. Paralleler Verlauf der Fortpflanzungsrate von Waldohreule (Asio otus) und Mäusebussard (Buteo buteo) [Parallel course of the reproduction rate of Long-eared Owl (Asio otus) and Common Buzzard (Buteo buteo)]. - Beiträge zur Vogelkunde 30: 1-11. (in German)

Wilson, D. 1975. The adequacy of body size as a niche difference. - American Naturalist 109: 769-784.

Zagorodniuk, I. 2006. Фауна в антропогенному середовищі [Fauna in anthropogenic environments]. - In: Zagorodniuk, I. (ed.) Proceedings of the Theriological School. - Luhansk, pp. 5-6. (in Ukrainian)

Witkowski, J. 1962. An analysis of the food of the town-nesting Kestrel (Falco tinnunculus). - Acta Universitatis Wratislav 1: 75-88.

Zaitseva, H. \& Hnatyna, O. 2009. Трофічні зв'язки сови вухатої (Asio otus L.) та дрібних гризунів (Rodentia) на території Шацького поозер'я [The trophic relations between the Long-eared Owl (Asio otus L.) and rodents (Rodentia) on the territory of Shatsk National Nature Reserve]. - Scientific Bulletin of Lesya Ukrainka Eastern European National University 2: 217-221. (in Ukrainian)

Zaytseva, H. \& Drebet, M. 2007. Роль мікромамалій у трофічному раціоні сови вухатої (Asio otus L.) на території Східного Поділля [The role of small mammals in the diet of Long-eared Owl (Asio otus L.) on the territory of Eastern Podillya]. - Proceedings of the State Natural History Museum 23: 205-214. (in Ukrainian)

Żmihorski, M. \& Rejt, Ł. 2007. Weather-dependent variation in the cold-season diet of urban Kestrels Falco tinnunculus. - Acta Ornithologica 42(1): 107-113. DOI:10.3161/000164507781646861

Zubarovsky, V. 1977. Хижі птахи [Birds of Prey]. - Naukova Dumka, Kyiv (in Ukrainian) 